\title{
Cat CAT-Scan: Postmortem Imaging and autopsy of two cats
}

\author{
Martinez, Rosa Maria ; Hetzel, Udo ; Thali, Michael J ; Schweitzer, Wolf
}

DOI: https://doi.org/10.1016/j.jofri.2014.11.004

Posted at the Zurich Open Repository and Archive, University of Zurich ZORA URL: https://doi.org/10.5167/uzh-102500

Journal Article

Accepted Version

Originally published at:

Martinez, Rosa Maria; Hetzel, Udo; Thali, Michael J; Schweitzer, Wolf (2015). Cat CAT-Scan: Postmortem Imaging and autopsy of two cats. Journal of Forensic Radiology and Imaging, 3(1):80-86.

DOI: https://doi.org/10.1016/j.jofri.2014.11.004 


\section{Author's Accepted Manuscript}

Cat CAT-Scan: Postmortem Imaging and autopsy of two cats

Rosa Maria Martinez, Udo Hetzel, Michael J. Thali, Wolf Schweitzer

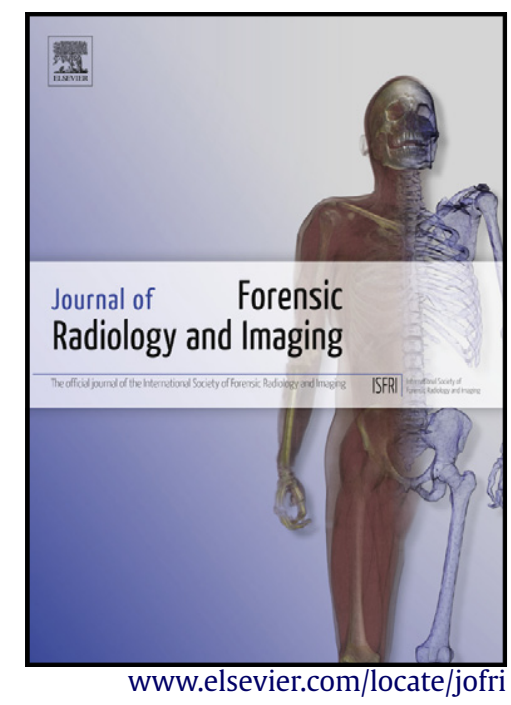

PII: S2212-4780(14)00120-8

DOI: $\quad$ http://dx.doi.org/10.1016/j.jofri.2014.11.004

Reference: JOFRI130

To appear in: Journal of Forensic Radiology and Imaging

Received date: 25 June 2014

Revised date: 29 September 2014

Accepted date: 7 November 2014

Cite this article as: Rosa Maria Martinez, Udo Hetzel, Michael J. Thali, Wolf Schweitzer, Cat CAT-Scan: Postmortem Imaging and autopsy of two cats, Journal of Forensic Radiology and Imaging, http://dx.doi.org/10.1016/j.jofri.2014.11.004

This is a PDF file of an unedited manuscript that has been accepted for publication. As a service to our customers we are providing this early version of the manuscript. The manuscript will undergo copyediting, typesetting, and review of the resulting galley proof before it is published in its final citable form. Please note that during the production process errors may be discovered which could affect the content, and all legal disclaimers that apply to the journal pertain. 


\title{
Cat CAT-Scan: Postmortem Imaging and autopsy of two cats
}

Rosa Maria Martinez ${ }^{1}$, MD, Udo Hetzel, Vet MD, Michael J. Thali ${ }^{1}$, Prof., MD, EMBA, Wolf Schweitzer ${ }^{1}$, MD

${ }^{1}$ Institute of Forensic Medicine, Department of Forensic Medicine and Imaging, University of Zurich, Winterthurerstrasse 190/52, 8057 Zurich, Switzerland

${ }^{2}$ Institute of Veterinary Pathology (IVPZ), University of Zurich, Oberstrass, 8057 Zurich, Switzerland

Corresponding Author

Rosa Maria Martinez, MD

Institute of Forensic Medicine

Department of Forensic Medicine and Imaging

University of Zurich

Winterthurerstrasse 190/52

CH-8057, Zurich

Switzerland

Tel: +41(0) 446355611

Fax: +41 (0) 446356851

Email: rosita.martinez@irm.uzh.ch

rosita.martinez@virtopsy.com

rosita.martinez@virtopsy.com

\begin{abstract}
A man killed his wife and their shared household cats before killing himself. The combination of the killing (suicide or homicide) of a family member and the pet is seen on occasions in forensic pathology. The purpose of this case report is to provide a comparison of the killing methods of animals, ill pets and of household animals, also in extended suicides or homicides given the initially outlined case.
\end{abstract}

Keywords: Forensic veterinary pathology, Virtopsy®, postmortem imaging, forensic autopsy, pet, cat, killing method.

\section{Introduction}

On occasion, forensic pathologists deal with cases of human corpses where their similarly dead household pet are found dead next to them. Hasegawa et al reported an assisted suicide of a woman and killing of the household dog by the husband with gunshots through the heads ${ }^{1}$. Cook described an extended suicide of a 
woman who killed herself and her pet dog by carbon monoxide poisoning ${ }^{2}$. Lew published a case where hanging was the method used for both spouses ${ }^{3}$.

Crime scene investigation, postmortem imaging (computed tomography (CT), magnetic resonance (MRI)) and autopsy are important parts of forensic investigations into the manners and causes of death. The woman died from blows to her head with a metal bar, whereas findings of death scene and post mortem examination suggested that one cat likely died from direct blows to its head, whereas the second cat's head probably was smashed against hard structures when swinging the cat by its tail. The man attempted to kill himself using sharp force injuries to arms and to the chest and neck region. As that appeared to have failed to kill him, he placed a plastic bag over his head and asphyxiated.

The purpose of this case report is to demonstrate postmortem imaging and autopsy findings, and to interpret the findings within the range of killing methods of unwanted or ill animals as opposed to killing of pet animals in extended suicides or homicides.

\section{Case description}

A 40 year old woman and her husband were found dead on the bed in their bedroom. Their flat was located in a rural area. Investigation of the scene identified a suicide note in the kitchen. There were veterinary prescription drugs present, with empty containers out on the kitchen sink. This suggested that an attempt at overdosing could have been made. The premises were not locked, and so the case was approached as a possible double homicide.

The body, the face and the head of the woman as well as the mattress cover and the clothes contained relatively large areas with blood. The wall near the head showed blood patterns indicative of blows with a heavy object, matching her head injuries as a consequence of blunt trauma. The external inspection of the woman's body demonstrated multiple wounds of the head, neck and throat as a result of blunt force. A knife was found next to the woman, which also showed adherent blood. There, also a metal rod of a weight lifting machine was found. A plastic bag was pulled over the head of the man, who was also lying on the same bed, and was affixed around the neck by multiple turns of adhesive tape. On removal, its inside was dripping wet. The area of the neck and chest of the man showed multiple cut and stab wounds. His left forearm also presented multiple parallel cuts.

In the living room, an adult dead cat (cat 1, grey-white) was discovered on the sofa. Its ear canal contained blood. Next to it, there was a cardboard piece exhibiting scratch marks. Another adult dead cat (cat 2, brownwhite) was found under the carpet on the floor of the bedroom without any evidence of external hemorrhage. In a utility room of the same flat, the edges of an unused metal dog cage and the nearby wall contained what appeared to be bits of cat hair and blood spatter suggestive of high velocity injuries to a cat.

The dog cage was present in the flat while the actual dog that explained the cage's presence - a German shepherd dog - was absent. That dog featured on a number of family pictures and appeared to have played a prominent role previously though. Its death had apparently preceded the current events even though further details could not be obtained. Furthermore, there were indications of the wife having an affair with another man.

A forensic autopsy of all bodies, including both cats, was ordered by the legal authorities to clarify manners and causes of deaths.

\section{Postmortem imaging, forensic autopsy and findings}

Prior to medicolegal dissection, postmortem multisclice computed tomography scans (PMCT) of both humans and cats were performed on a dual-source CT scanner (Flash Definition, Siemens, Forchheim, Germany). Scan parameters contained a tub voltage of $120 \mathrm{kVp}$, automatic dose modulation (CARE dose 4D, Siemens,

Forchheim, Germany), slice thickness $1.0 \mathrm{~mm}$ and increments of $0.6 \mathrm{~mm}$. Reconstructions were done using soft and hard reconstruction kernels.

Forensic autopsies of the human corpses were performed by a team of two forensic pathologists. Forensic autopsies of the cats were performed by a veterinary pathologist with experience in forensics and a team of two 
forensic pathologists. All examinations reported here were authorized by the judiciary investigation into this case.

\section{Humans}

Postmortem imaging of the woman showed burst fractures of the skull and pronounced gas embolism in the veins of the neck and right heart. In addition the neck showed fractures of the first and third cervical vertebrae as well as hemorrhages of the soft tissue. The forensic autopsy of the wife verified multiple blunt force in the form of blows against the head with a hard object - possibly the metal rod - and evidence of strangulation. The skull fracture had lacerated veins, over which air entered the vascular bed and which in due lead to a gas (air) embolism and subsequent cardiac arrest. Toxicological tests found a blood alcohol of $0,88 \mathrm{~g} \%$, but routine screening for other substances was negative. The cause of death was issued as heart failure due to gas embolism, as consequence of homicidal blunt head trauma. The manner of death was classified as a homicide.

PMCT of the man showed soft tissue emphysema of the throat and density variations in the soft tissue of the left breast, there, were the cut and stab wounds were located. Dissection of the man's body demonstrated 10 wounds in the area of the throat, breast and both forearms as a result of sharp force without injury of vital structures. Moreover he showed emphysema of the lung. Toxicological analysis showed a blood alcohol concentration of $0,87 \mathrm{~g} \%$, and no other substances in routine and screening of blood and renal tissue. Due to the finding of the plastic bag over the head and exclusion of other causes of death, cause of death was issued as external asphyxiation due to suicidal application of a plastic bag over his head. The manner of death was suicide.

Cats

CT scan of cat 1 demonstrated a comminuted fracture of the skull, a fracture of the left mandibula and scapula as well as soft tissue emphysema of the head. The autopsy could confirm the comminuted fracture of the skull of cat 1 and severe injury of the brain. Furthermore, there were extensive and deep hemorrhages and contusions of fat tissue and muscles of the neck.

Cat 2 had soft tissue emphysema of the throat and in the region of the rear legs adjacent to the pelvic bone. Fat and muscles in the neck region were extensively contused. Also, there were subcutaneous hemorrhages at the tail's insertion to the body.

The additional analysis of a pulmonary fat embolism presented a moderate to profound respectively a minimal to moderate pulmonary fat embolism (Grade II to III, respectively I to II, according to Falzi et al ${ }^{4}$ ) in cats 1 and 2 , respectively. Additional toxicological analysis were negative in both cases.

Both bodies lacked visible signs of post mortem decomposition also in PMCT. Autopsies and imaging were performed after the bodies had been on the death scene for about 12 hours and in cooled storage for another 18 hours. Trace levels of ethanol were found in cat $1(0,05 \mathrm{~g} \%$ ) and cat $2(0,03 \mathrm{~g} \%$ o) and interpreted as signs of beginning decomposition. Also, the veterinary pathologist stated that both cats were in a good state of health previous to their demise. Both cats were also sampled for trace and DNA evidence.

Conclusion of case investigation

The forensic and criminalistic examinations on the scene suggested that the husband killed his wife and the pets, and then himself.

\section{Discussion}

Any forensic pathologist may run into dead animals, possibly pets, particularly when going out on death scenes of humans. Especially in unclear cases, their examination may yield additional reconstructive angles.

Time of death estimates can be relevant in any possibly homicidal case. In this instance, a considerably shorter post mortem interval for both or one of the cats in this case might have raised relevant questions, also as to third 
party involvement. Presence of their well groomed body cover (fur) was documented photographically and in PMCT. Fur is widely accepted as insulating against cooling. Compared to quantified thermal insulation of normal human clothing 5 (around 1-2 clo), furry animals ${ }^{6-7}$ easily go beyond that (e.g., house cat: over 4.4 clo; coyote: $4.7 \mathrm{clo})^{8}$. Faster decomposition rates are to be regarded as well established due to delayed body cooling when higher thermal insulation is present ${ }^{9}$. So in this case, the cats appeared to exhibit slightly more advanced stages of post mortem decomposition than the humans. Considering thermal insulation, this was still judged to not constitute a widely differing time of death ${ }^{10}$.

Cause of death may not be obvious and not be restricted to physical violence, so toxicology should always be considered as well. Here, poisoning was suspected at first, but did not find confirmation upon toxicological analysis. Some animals have musculoskeletal systems that sustain comparatively high forces ${ }^{11}$, and so macroscopically visible skeletal injuries - as in these cats - may reflect considerably large forces less than one would expect them to be coming from (human) forensic pathology. Not always is a veterinary pathologist available to conduct a full autopsy for reconstructive purposes on short notice, but to get verbal guidance or expert opinion for interpreting findings may be of importance. Postmortem imaging, including the search for soft tissue emphysema, may thus add relevant reconstructive aspects to the examination.

Pets as members of their family risk getting killed, in what one may regard as extended suicides, along with the spouses and children of the offenders ${ }^{2}$. The methods matter in that in forensically investigated cases of extended suicides with pets, the same method in human and animal was described as far as previously published cases go. There was one case of cerebral injury by gunshot to both the animal and then the human ${ }^{1}$. In another case, both human and pet died of carbon monoxide poisoning ${ }^{2}$.

In the present case, the offender used several different forms of violence: the wife was beaten to death using an iron bar. The household cats were killed by blunt force, one by applying direct blunt force while using a cardboard as a shield to defend against scratching. The second cat was likely killed by swinging it by its tail and having it suffer blows against the head by smashing the head against hard structures. The man then attempted suicide by first stabbing himself into the chest and by cutting his wrists. He managed to suffocate himself by putting his head under a plastic bag and sealing that around his neck by virtue of sticky tape.

Discussing and considering the classification into manners of death represents a uniquely forensic aspect of death investigation that can be both conceptually demanding and difficult ${ }^{12-13}$. Homicidally extending a suicide onto other family members, thus creating at least a dyadic death, can be analyzed from various angles ${ }^{14}$. With that, the relationship between homicidal or suicidal death of owners and their pets has to be termed particularly complex.

In one very interesting instance, a parrot that survived his owner's homicidal demise later provided the investigative authorities with a lead angle on the perpetrator ${ }^{15}$. This case implies that any possibly present parrots might get killed as possible witness or evidence. So in such an instance, the motive for killing the pet might be similar to the motives for killing a witness.

Pets may try to defend their owners aggressively and thus motivate the assailant to kill the pet to defend themselves ${ }^{16-17}$.

Furthermore, the killing of an animal, possibly a loved animal, as part of an extended suicide, or as part of homicidal killing of humans, appears to be not as clearly delineated against "nonviolent" killings of animals as it is done under the umbrella term of "euthanasia" as one might wish. After all, lack of home and caretaker is a verbally explicitly listed reason for animal euthanasia ${ }^{18}$.

In one case a man killed his next door neighbors and their dogs before committing suicide, apparently touched off by loud barking ${ }^{19}$. Obviously, we would not use the word euthanasia in this instance. Much rather, we would term the death of these animals (and the neighbor family) a murder, probably not even an extended suicide. In another instance however, a millionaire killed his wife and daughter alongside their dogs and horses before committing suicide ${ }^{20}$ in what we would clearly term an extended suicide. 
Whether "euthanasia" is the right term for not letting pet type animals, in this particular instance, suffer deprivation of their loved owner, is unclear. And yet, suicides of animals after being deprived of their presumably loved owners also are documented in rare $\operatorname{cases}^{21}$.

If a murderer foresees or respects impending lack of caretakership when killing pets alongside their owners, if they want to silence a possible witness, or if they kill an animal out of defense remains to be determined by investigations and courts. Other combined animal and human death cases cover incidents termed hunting accidents, but obscure homicides or homicide attempts may be among these too ${ }^{22-23}$.

Consequentially, a killing method used in more typical cases of animal euthanasia ${ }^{24-25}$ possibly used in extended suicide is conceivable in cases where the pet owner is a veterinarian or has experience in veterinary medicine or practice. Furthermore, the veterinary euthanasia derived Natriumpentobarbital is used also for assisted suicides. It will probably be a matter of time until right-to-die organizations will see requests of suicidants to extend their suicide assistance also to putting a pet to sleep forever. Only toxicology, however, will show whether any given pet died from poisoning.

Also, owner suicides were reported days after natural or euthanasia death of a beloved pet in some instances ${ }^{26-27}$. In this case, death of a beloved dog had preceded the dyadic death even though the dog's death was not mentioned in the suicide note. Last but not the least, relationship problems also have to be considered as a factor in dyadic deaths ${ }^{28}$.

Although there are specific laws to protect animals, in rural areas, supernumerary kittens may be killed by their owners often by mechanical methods, for example by bashing the head, drowning in water, or they are suffocated by disposing of them in fodder silo's or gassing them in plastic bags using motor vehicle exhausts ${ }^{29-30}$. Bashing or bludgeoning animals to death may point to a rural background of the killer. In Switzerland, torturing animals may be prosecuted ${ }^{31}$.

In societies with high rates of interhuman violence, animals also are more common targets for violent acts ${ }^{32}$. In a review study of 191 autopsy cases performed on domestic cats in Brazil an analysis of the causes of death showed that approximately $30 \%$ of cats died due to non-accidental injuries as an indication of the widespread violent behavior of humans against animals ${ }^{32}$.

In summary, the attribution of the term "euthanasia" to willfully killing animals (i.e., attempting doing the animal a favor by relieving it from possible future suffering) to extended suicide (i.e., prioritizing the suicidal death of the animal killer in naming the manner of death) or homicide (for which there also are clear examples) can be difficult in any given instance. Difficulty is technical (can the motives of the killer be clearly established?) and moral (in what way does killing an animal do that animal a favor, given that at any later point in life the animal might have died anyway)?

Analysis of wounds and injury patterns may be considered for discrimination between all homicide cases and extended suicides; Betz and Eisenmenger (1997) found that homicides on an average showed two or three different types of trauma in $29 \%$, whereas only one type of injury was prevalent in extended suicides (90\%). They concluded that different modes of killing were unusual in dyadic deaths ${ }^{33}$. In relation to the mode of killing being employed across other published cases, there are clearly homicidal death scenes where only one method (i.e., shooting) was used, but there are also cases of extended suicides, that also feature the same method across both human and animal victims ${ }^{1-2}$. Yet in this instance, a variety of methods were applied (rather than one). Such „complex suicide“ (suicides committed by using more than one method) can be observed in apparently planned or unplanned cases ${ }^{34,35}$. In unplanned complex suicides, the mode of performance may be changed after the first method chosen failed or was working too slow or proved to be too painful, and then, frustrate attempts often times can be seen. In this instance, strangulation of the wife could represent a failed homicidal attempt, but it could also be a consequences of preceding domestic violence within a dispute and fight. Battery before dyadic death has been reported previously ${ }^{36(\mathrm{p}-)}$. The offender's sharp force injuries represent a failed suicide attempt in this case.

Last but not the least, animals may exhibit less mental restrictions to physically fight off a possible intruder or offender than humans, particularly when facing a well known person. In this instance, cat 1 was found next to a 
cardboard piece whose scratch marks clearly show that it was used as a shield. So the cats paws in particular are of high interest. Possible DNA evidence particularly on the fur of cat two's behind (including legs and tail) only became a closer consideration after PMCT showed soft tissue emphysema around the legs. If any other person was to be included in this case as suspect, linkage evidence was likely present also on one or both cats, and post mortem investigation would also lead the way to particular areas of interest - in this instance, paws, legs hip and tail regions - there.

Generally, it is important to extended investigations into the cause of death and reconstruction of a crime scene using postmortem imaging and forensic dissection and toxicological analysis to both human and animal victims. Even then, finding the proper terms for categorizing these deaths within the vocabulary of forensic medicine can be difficult.

\section{Conflicts of Interest}

None declared.

\section{Acknowledgements}

The authors would like to thank Dominic Gascho, Radiographer, for his excellent work and assistance in acquiring and processing the data.

\section{References}

1. Hasegawa I, Gehl A, Nushida H, Püschel K. Assisted suicide and killing of a household pet: preautopsy post-mortem imaging of a victim and a dog. Forensic Sci. Med. Pathol. 2014;10(1):122125. doi:10.1007/s12024-013-9498-3.

2. Cooke BK. Extended suicide with a pet. J. Am. Acad. Psychiatry Law 2013;41(3):437-443.

3. Lew EO. Homicidal hanging in a dyadic death. Am. J. Forensic Med. Pathol. 1988;9(4):283-286.

4. Falzi G., Henn R., Spann W. Über pulmonale Fettembolien nach Traumen mit verschieden langer Überlebenszeit. Münch Med Wochenschr 1964;106:978-981.

5. Gagge AP, Nishi Y. Heat Exchange Between Human Skin Surface and Thermal Environment. In: Terjung R, ed. Comprehensive Physiology. Hoboken, NJ, USA: John Wiley \& Sons, Inc.; 2011. Available at: http://www.comprehensivephysiology.com/WileyCDA/CompPhysArticle/refIdcp090105.html. Accessed September 29, 2014.

6. Scholander PF, Walters V, Hock R, Irving L. Body Insulation of Some Arctic and Tropical Mammals and Birds. Biol. Bull. 1950;99(2):225-236. doi:10.2307/1538740.

7. Scholander PF, Hock R, Walters V, Irving L. Adaptation to cold in arctic and tropical mammals and birds in relation to body temperature, insulation, and basal metabolic rate. Biol. Bull. 1950;99(2):259-271. 
8. Hammel HT. Thermal properties of fur. Am. J. Physiol. 1955;182(2):369-376.

9. Henssge C, Madea B. Estimation of the time since death. Forensic Sci. Int. 2007;165(2-3):182184. doi:10.1016/j.forsciint.2006.05.017.

10. Munro R, Munro HMC. Some Challenges in Forensic Veterinary Pathology: A Review. J. Comp. Pathol. 2013;149(1):57-73. doi:10.1016/j.jcpa.2012.10.001.

11. Vnuk D, Pirkić B, Maticić D, et al. Feline high-rise syndrome: 119 cases (1998-2001). J. Feline Med. Surg. 2004;6(5):305-312. doi:10.1016/j.jfms.2003.07.001.

12. Mind Your Manners: Part I: History of Death Certification an... : The American Journal of Forensic Medicine and Pathology. Available at: http://journals.lww.com/amjforensicmedicine/Fulltext/1997/09000/Mind_Your_Manners_Part_I _History_of_Death.1.aspx. Accessed September 29, 2014.

13. Mind Your Manners: Part II: General Results From the Nationa... : The American Journal of Forensic Medicine and Pathology. Available at: http://journals.lww.com/amjforensicmedicine/Fulltext/1997/09000/Mind_Your_Manners_Part_II _General_Results_From.2.aspx. Accessed September 29, 2014.

14. Berman AL. Dyadic Death: Murder-Suicide. Suicide Life. Threat. Behav. 1979;9(1):15-23. doi:10.1111/j.1943-278X.1979.tb00899.x.

15. Talking parrot "helps" UP Police crack murder case - The Times of India. Available at: http://timesofindia.indiatimes.com/india/Talking-parrot-helps-UP-Police-to-crack-murdercase/articleshow/31057661.cms?utm_source=facebook.com\&utm_medium=referral. Accessed September 4, 2014.

16. Doppel-Mord von Gütersloh: Hat Mischling Benny den Killer gebissen? - News Inland - Bild.de. Available at: http://www.bild.de/news/inland/mord/hat-mischling-benny-den-killer-gebissen34016570.bild.html. Accessed September 4, 2014.

17. SR-online: Hat der Hund den Mörder gebissen? Available at: http://www.sronline.de/sronline/nachrichten/panorama/toter_bismarckstr104.html. Accessed September 4, 2014.

18. Animal euthanasia - Wikipedia, the free encyclopedia. Available at: https://en.wikipedia.org/wiki/Animal_euthanasia\#Reasons_for_euthanasia. Accessed September 4, 2014.

19. Phoenix man murders neighbors and their dogs before killing himself - NY Daily News. Available at: http://www.nydailynews.com/news/national/phoenix-man-kills-neighbors-dogs-article1.1498348. Accessed September 4, 2014.

20. Revealed: Why millionaire Christopher Foster slaughtered his family I Mail Online. Available at: http://www.dailymail.co.uk/news/article-1167196/Revealed-Why-millionaire-Christopher-Fosterslaughtered-family.html. Accessed September 4, 2014.

21. "I had a sexual relationship with a dolphin"। New York Post. Available at: http://nypost.com/2014/06/10/the-dolphin-that-fell-in-love-with-a-human/. Accessed September $29,2014$.

22. Jagdunfall in Brandenburg: Jäger erschießt Jäger - Ohne Jagdschein I Brandenburg - Berliner Zeitung. Available at: http://www.berliner-zeitung.de/brandenburg/jagdunfall-in-brandenburgjaeger-erschiesst-jaeger---ohne-jagdschein,10809312,24120714.html. Accessed September 4, 2014. 
23. Jagdunfälle. Available at: http://www.vogelschutz-komitee.de/index.php/jagd/jagdunfaelle. Accessed September 4, 2014.

24. CPT: CliniPharm/CliniTox. Available at: http://www.vetpharm.uzh.ch/perldocs/index_y.htm. Accessed September 4, 2014.

25. Hess L, Applegate JR, Bloss JR, et al. Euthanasia: considerations, concerns, and complications. J. Avian Med. Surg. 2013;27(1):53-58.

26. 2012 ASAI 1 F. Nick Santino Commits Suicide After Euthanizing Dog. Vetstreet. Available at: http://www.vetstreet.com/our-pet-experts/an-actors-death-puts-a-spotlight-on-breed-bans-andgrieving-over-the-loss-of-a-pet. Accessed September 29, 2014.

27. Grief-stricken cat owner, 44, killed himself "because he couldn"t get over the death of his beloved tabby'. Mail Online. Available at: http://www.dailymail.co.uk/news/article2141256/Bournemouth-man-commits-suicide-cats-death.html. Accessed September 29, 2014.

28. Jerzy Kunz FB. [Medicolegal problems of \&quot;dyadic death\&quot;]. Arch. Med. Sadowej Kryminol. 2002;52(3):163-76.

29. Katzenmord. Available at: http://www.tierheim-rottach.de/HTML/Katzenmord.htm. Accessed September 4, 2014.

30. Darf man Katzen einfach töten? Available at: http://www.katzenmagazin.ch/darf-man-katzeneinfach-toten/. Accessed September 4, 2014.

31. SR 455 Tierschutzgesetz vom 16. Dezember 2005 (TSchG). Available at:

http://www.admin.ch/opc/de/classified-compilation/20022103/index.html. Accessed September 4, 2014.

32. De Siqueira A, Cassiano FC, de Albuquerque Landi MF, Marlet EF, Maiorka PC. Non-accidental injuries found in necropsies of domestic cats: a review of 191 cases. J. Feline Med. Surg. 2012;14(10):723-728. doi:10.1177/1098612X12451374.

33. Betz P, Eisenmenger W. Comparison of wound patterns in homicide and dyadic death. Med. Sci. Law 1997;37(1):19-22.

34. Bohnert M, Pollak S. [Complex suicides--a review of the literature]. Arch. Für Kriminol. 2004;213(5-6):138-153.

35. Vogel D, Hammer U, Büttner PDA. Ungeplant komplexer Suizid. Rechtsmedizin 2011;21(1):4850. doi:10.1007/s00194-010-0731-z.

36. Homicide-suicide (dyadic death), homicide, and firearms use in England and Wales. Available at: http://www.pubfacts.com/detail/18043018/Homicide-suicide-dyadic-death-homicide-andfirearms-use-in-England-and-Wales. Accessed September 29, 2014.

\section{Legend}

Figure 1: Postmortem imaging of cat 1: Some animals have musculoskeletal systems that sustain comparatively high forces and so macroscopically visible skeletal injuries may not occur. Then, post mortem imaging may add relevant reconstructive aspects to the examination. This figure shows the comminuted fracture of the skull (A) and fracture of the scapula (B) after blunt force with blows against the head and neck. 
Figure 2: Postmortem imaging of cat 1: Soft tissue emphysema can be the only sign of blunt force. The figure demonstrates soft tissue emphysema of the head (compare the 3D image here to the 3D reconstruction of cat 2). Arrows in axial images indicate trapped gas.

Figure 3: Dissection of cat 1: It is important to investigate the cause of death and reconstruction of a crime scene using post mortem imaging and forensic dissection of both the human and animal victims. The figure shows th musculature of head, neck and back from dorsal view with multiple crushes and bleedings after blunt force with blows against the head and neck.

Figure 4: Postmortem imaging of cat 2: Three dimensional CT reconstruction: Soft tissue emphysema of the throat and hip (arrows).

Figure 5: Postmortem imaging of cat 2: Soft tissue emphysema of the throat (arrows).

Figure 6: Dissection of cat 2: Removed skin and subcutis fat tissue with crushes and bleedings in the area of head and neck.

Figure 7: Dissection of cat 2: Neck from dorsal view: superficial and deep crushes and bleedings of the muscles of the neck.

\section{Highlights}

- Combination of killing of a family member and the own pet is not rare

- There are different methods of killing animals

- The killing method is often the same in human and animal

- Investigation of human and animal victims is important to reconstruct a crime scene 


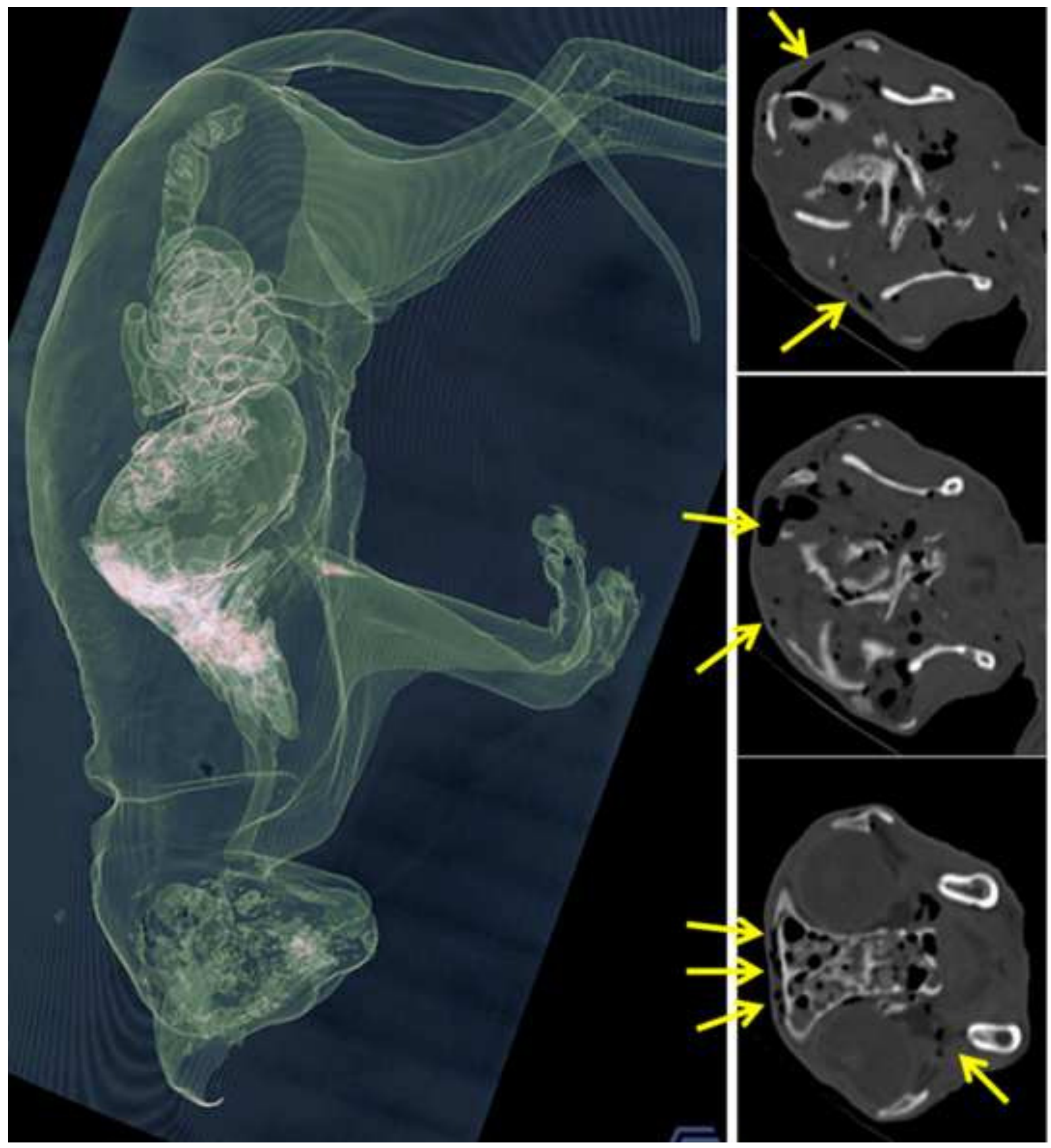




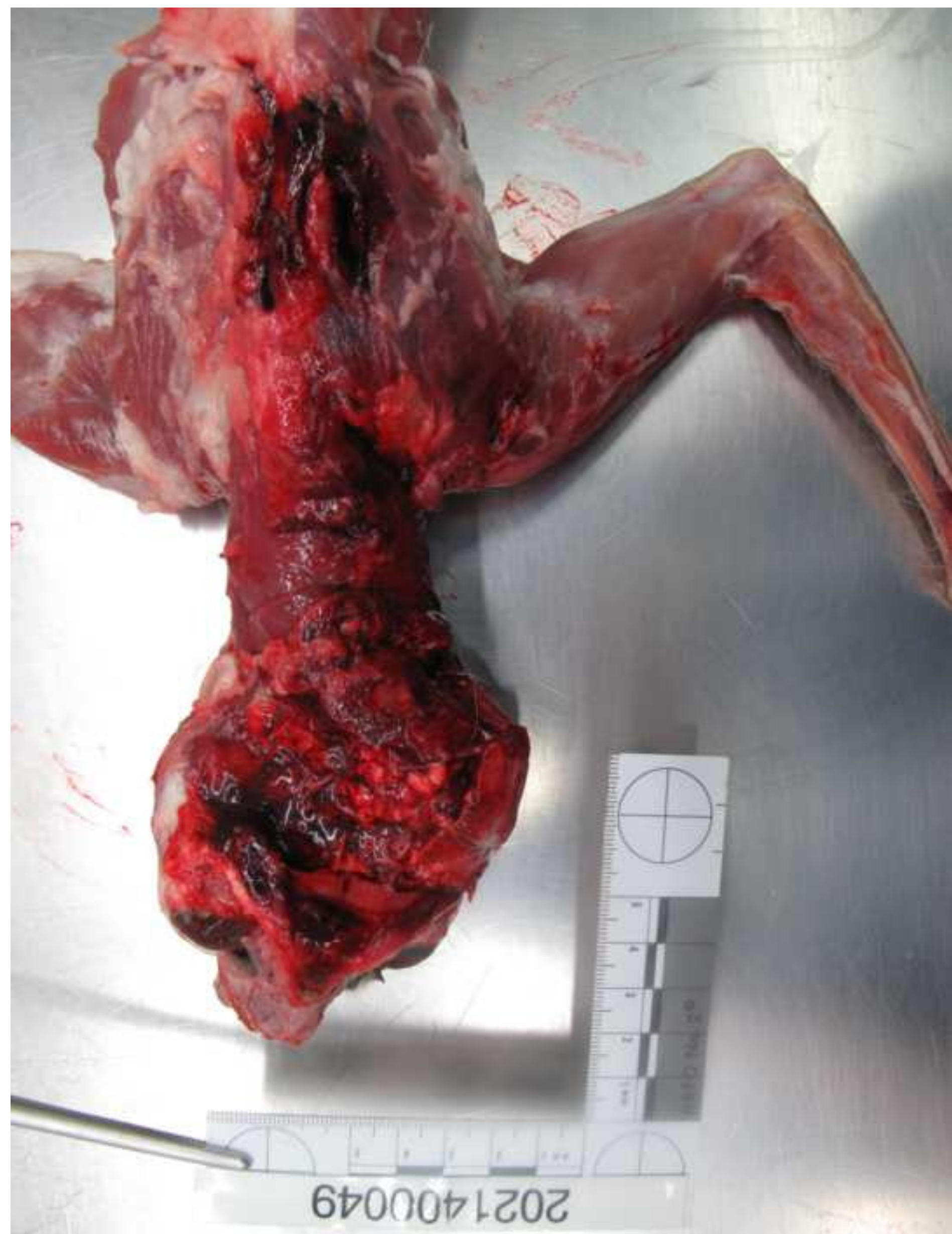




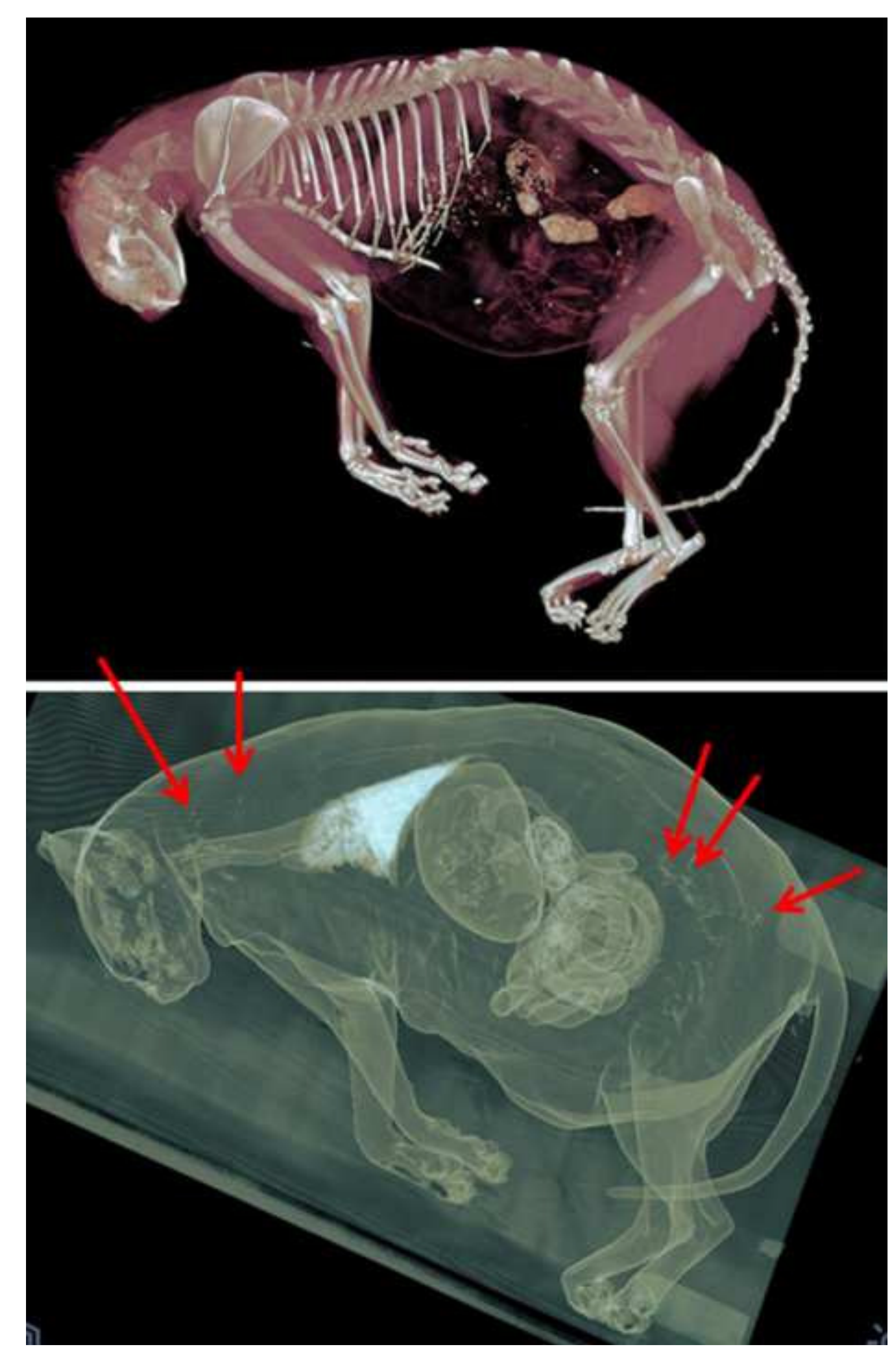

\section{(2.}

.
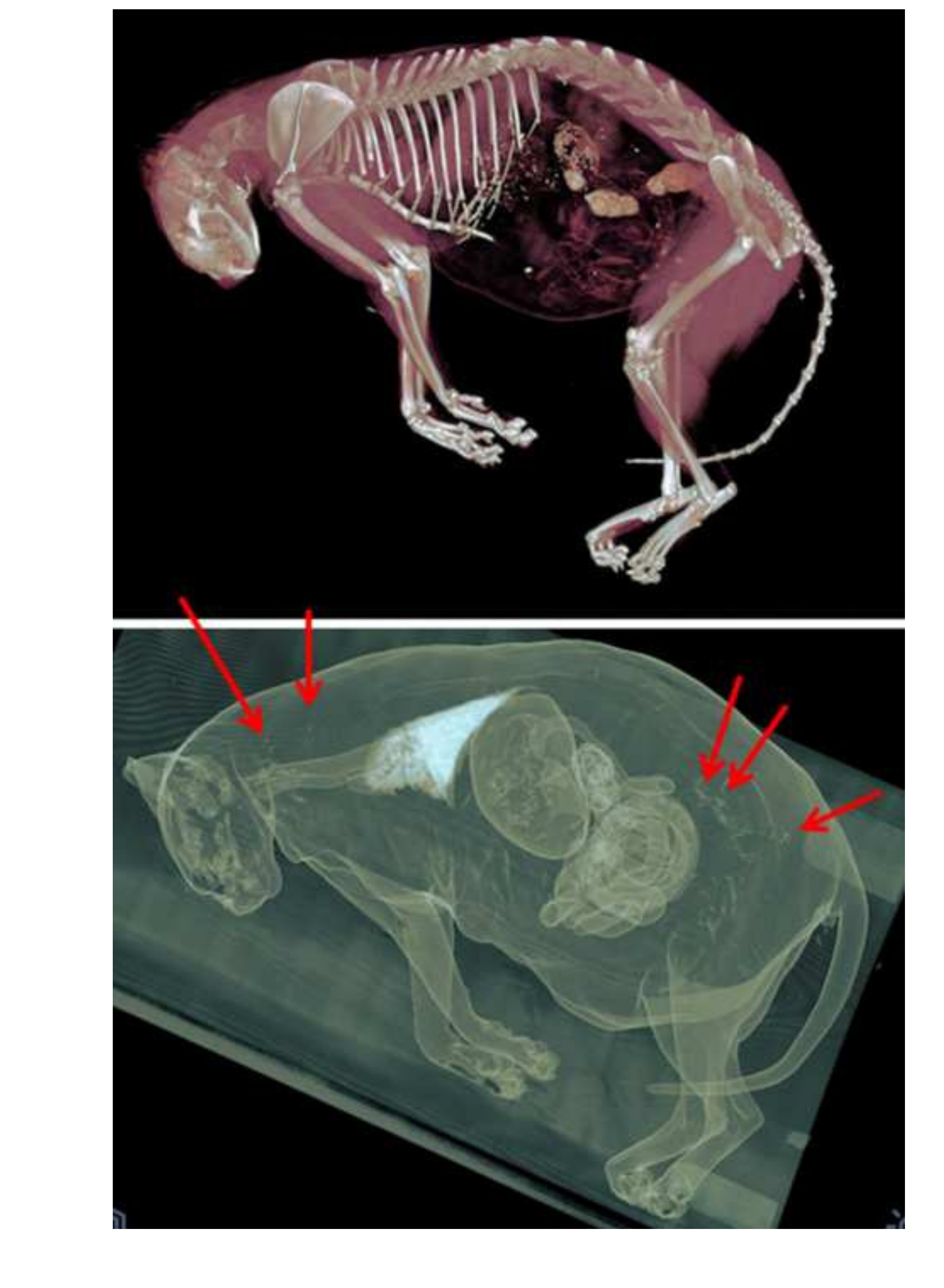


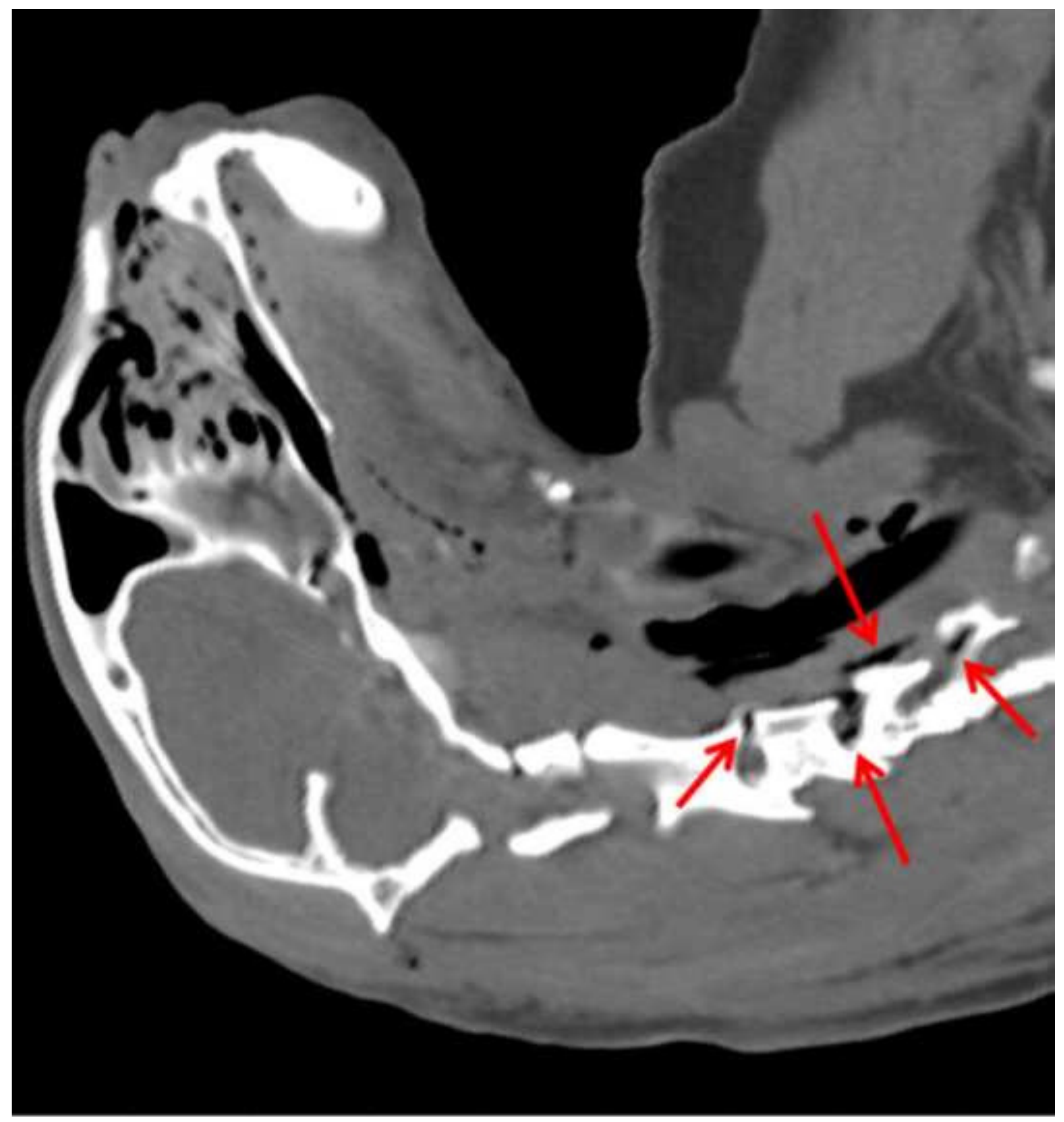




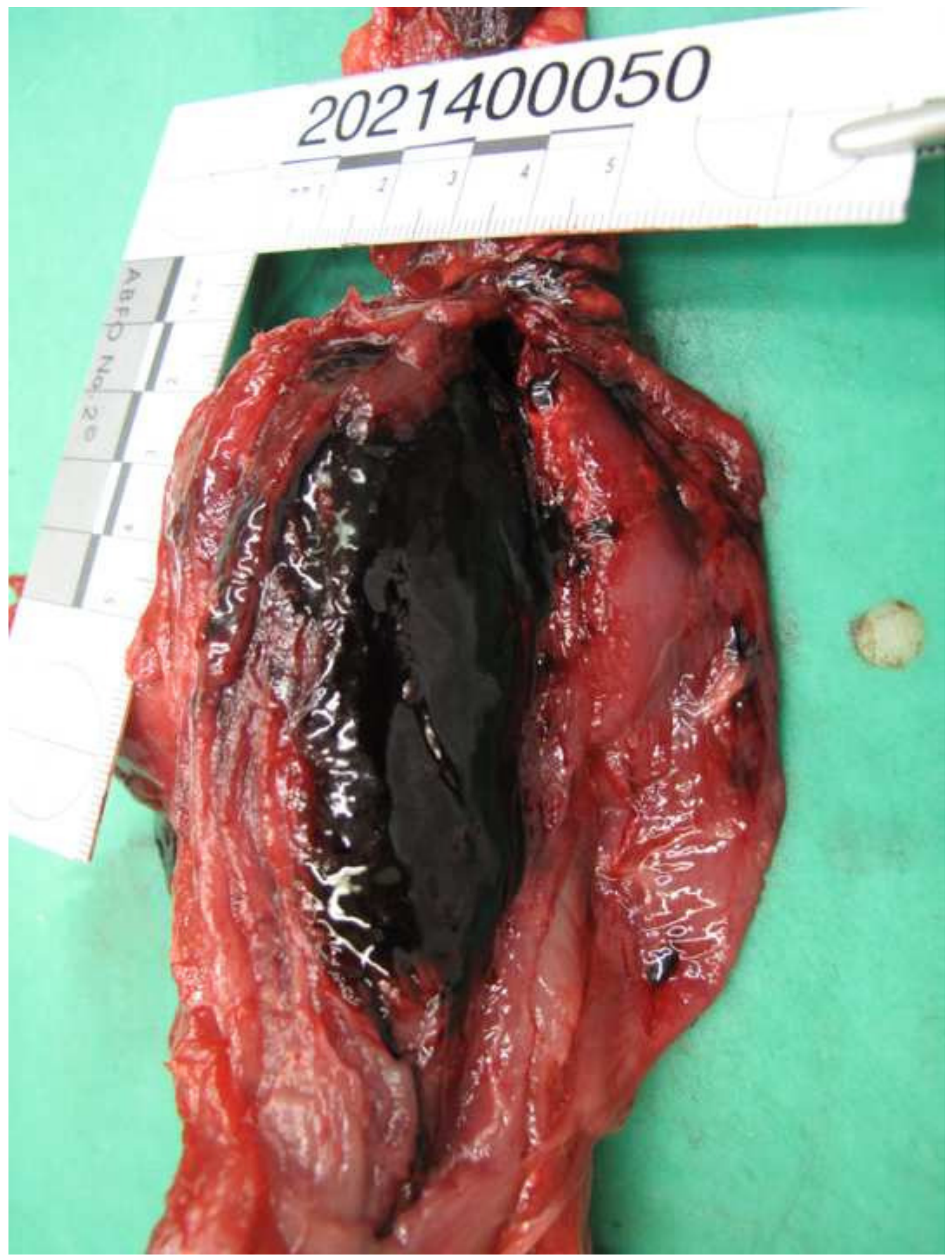




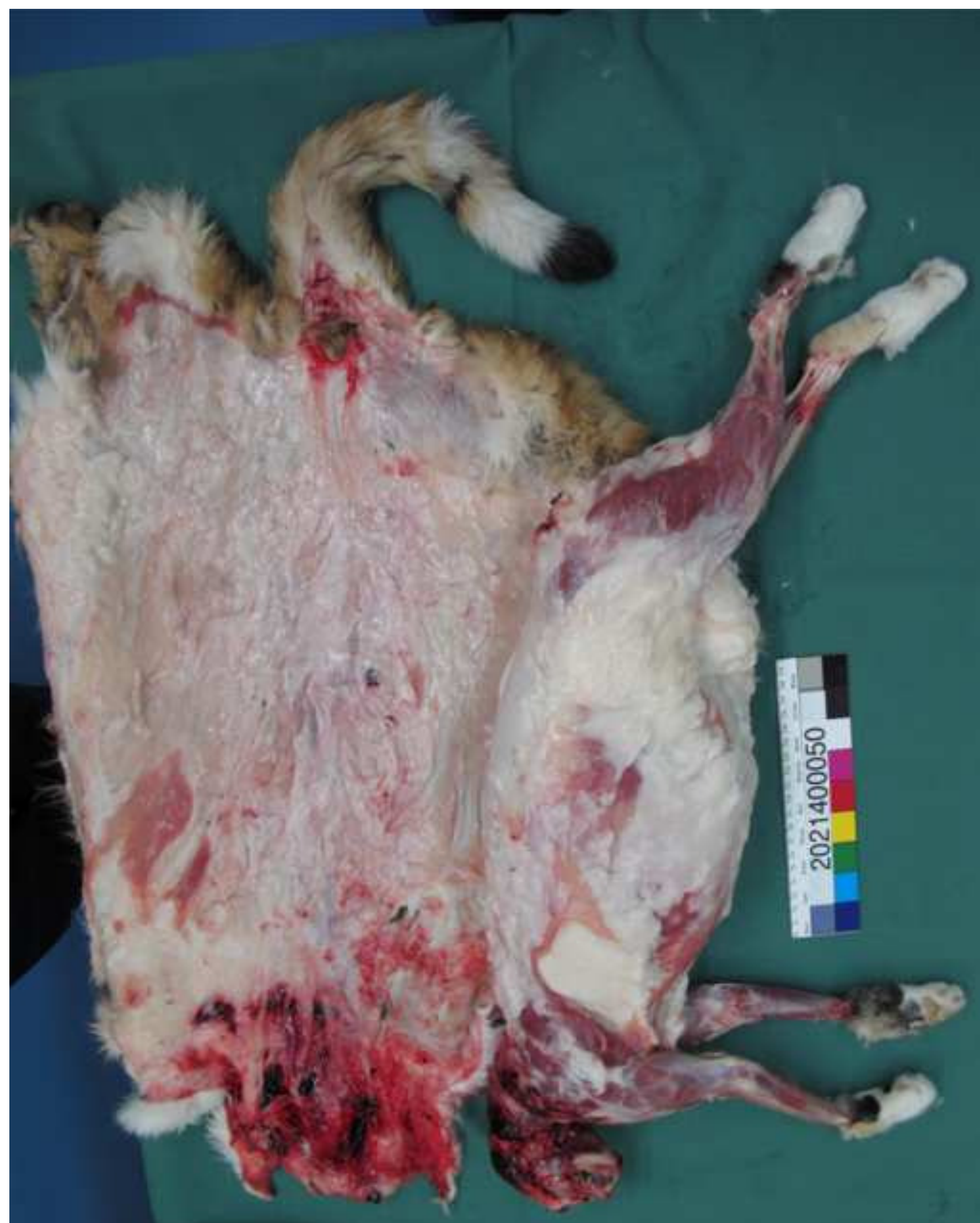

